\title{
Correction to: Topical Glycopyrronium Tosylate in Primary Axillary Hyperhidrosis: A Profile of Its Use
}

\author{
Yvette N. Lamb ${ }^{1}$
}

Published online: 28 November 2019

(c) Springer Nature 2019

\section{Correction to: \\ Clinical Drug Investigation (2019) 39:1141-1147 https://doi.org/10.1007/s40261-019-00853-x}

The article Topical Glycopyrronium Tosylate in Primary Axillary Hyperhidrosis: A Profile of Its Use, written by YN Lamb, was originally published Online First without Open Access. After publication in volume 39, issue 11, pages 1141-1147, Dermira, Inc. requested that the article be Open Choice to make the article an open access publication. Post-publication open access was funded by Dermira, Inc. The article is forthwith distributed under the terms of the Creative Commons Attribution-NonCommercial 4.0 International License (http://creativecommons.org/licen ses/by-nc/4.0/), which permits any noncommercial use, duplication, adaptation, distribution and reproduction in any medium or format, as long as you give appropriate credit original author(s) and the source, provide a link to the Creative Commons licence and indicate if changes were made.

The original article has been corrected.

Open Access This article is distributed under the terms of the Creative Commons Attribution-NonCommercial 4.0 International License (http://creativecommons.org/licenses/by-nc/4.0/), which permits any noncommercial use, distribution, and reproduction in any medium, provided you give appropriate credit to the original author(s) and the source, provide a link to the Creative Commons license, and indicate if changes were made.
The original article can be found online at https://doi.org/10.1007/ s40261-019-00853-x.

Yvette N. Lamb

demail@springer.com

1 Springer Nature, Private Bag 65901, Mairangi Bay, Auckland 0754, New Zealand 